\title{
The Influence of E-Learning and Learning Interests on Learning Outcomes of Physical Education in 11th Students of SMA Negeri 8 Medan
}

\author{
Denny Syahputra Panjaitan ${ }^{1}$, Nurhayati Simatupang ${ }^{2}$, Sanusi Hasibuan $^{3}$, Indrakasih ${ }^{4}$ \\ ${ }^{1,2,3,4}$ Sports Education, Universitas Negeri Medan, Indonesia \\ dennypanjaitannovember1993@gmail.com
}

\begin{abstract}
The purpose of this study was to explain the effect of differences in learning outcomes of physical education through edmodo and google classroom on Class XI students of SMA Negeri 8 Medan. This research method uses an experimental method with a $2 \times 2$ level design. The data analysis technique used analysis of variance. The research instrument used a questionnaire. The results of the research that have been carried out state that: (1) Based on the results of the analysis of variance in the list of attachments at the level of $\alpha=0.05$, it is obtained that $F 0<F t$ is $0.279<4.11$. (2) Then in the Tukey test in groups A1B1 and A2B1 where $=1.681$ and $=2.95$. Research conclusions: 1) There are differences in physical education learning outcomes through edmodo and google classroom.
\end{abstract}



\section{Introduction}

Learning is essentially a cognitive process that has the support of psychomotor functions. The psychomotor function in the learning manifestations carried out by students, almost certainly always involves a function of the realm of reason whose intensity of use is certainly different from other learning events. So the teacher's job is to give examples of the use of cognitive strategies that are appropriate, meaning that they are in accordance with the general capacity of students and in accordance with the needs and levels of difficulty of the material to be taught to them. (Arsani et al, 2020)

E-Learning consists of two parts, namely: "E" which stands for "electronic" and "Learning" which means learning using electronic device assistance services, especially computer devices. Therefore, e-learning is often referred to as online courses. In other words, e-learning or learning through online is learning whose implementation is supported by technology services such as telephone, audio, video tape, satellite or computer transmission. Onlinecurse is how to take advantage of ICT (Information and Communication Technology) for distance education so that those who want education can be more accessible.

According to Andriani (2003: 305) e-learning is a form of distance learning (PJJ). Those that utilize telecommunication and information technology, for example the internet, video / audiobrodcasting, video / audioconferencing, CD-Room (Synchronous and asynchronous). Furthermore, according to Dewi Salma (2007: 240) Thus, e-learning or online learning is learning whose implementation is supported by technology services such as telephone, audio, videotape, satellite or computer transmission.

During the pandemicovid-19 period, all schools were closed to study at home. Automatically learn at home via distance and involve e-learning in learning. One of them 
is learning physical education which is quite difficult to implement in online learning. Physical education is one of the subjects in schools which is a means of encouraging the development of motor skills, physical abilities, knowledge, sportsmanship, habituation of healthy lifestyles and character building (mental, emotional, spiritual and social) in order to achieve the goals of the national education system.

Physical education is different from the sport, because of the physical education teaching physical activity that aims to maintain a healthy body, strengthen muscles, and shape the character of the students, while in sport there are physical activities that require high-level skills and in actual use rules that have been agreed upon. Implementation of learning sports physical education and health in primary schools there are not in accordance with the concept of learning sports physical education and health. (Novianti et al, 2020)

Physical education is useful for increasing quality human resources both in terms of physical, spiritual, such as affective and cognitive as well as psychomotor. Physical activities that are carried out only by prioritizing physical activity alone will not lead students to think and take the values contained in the game will not be useful in everyday life. Physical Education is a lesson that contains many character values that are useful for everyday human life. Physical Education is one of the subjects that are carried out to form a child's physical body so that they can maintain fitness, but apart from that through Physical Education, children also learn to form positive characters that can be useful in social life.

The objectives of Physical Education, Sports and Health include: (1) developing selfmanagement skills in an effort to develop and maintain physical fitness and a healthy lifestyle through various selected physical activities and sports, (2) increasing physical growth and better psychological development. , (3) improving basic movement skills and abilities, (4) laying a strong moral character foundation through internalization of the values contained in Physical Education, sports and health, (5) developing sportsmanship, honesty, discipline, responsibility, cooperation , self-reliant and democratic, (6) developing skills to maintain one's own safety,other people and the environment and (7) understand the concept of physical activity and exercise in a clean environment as information to achieve perfect physical growth, healthy lifestyles and fitness, skills, and have a positive attitude (Depdiknas, 2003: 11).

Physical education researchers and teachers at SMA Negeri 8 Medan realized that during the pandemic, online learning for learning motion was very difficult to do. Becoming a physical education teacher is much more complicated than any other field of study at this time. As a learning experience encapsulated in a curriculum, physical education is more complicated for several reasons. First, the goal to be achieved is comprehensive, because it is not only to improve the physical aspect with several relevant elements, for example to stimulate the growth and development of organs. Second, the achievement of the intended objectives depends on teaching tasks, in this case, in the form of physical activities in the form of playing activities or sports. Third, how teaching methods to deliver teaching tasks as a stimulus for growth also contribute to the achievement of educational goals. Fourth, environmental factors which include physical aspects, such as sports facilities and infrastructure determine whether teaching and learning activities can run smoothly. Fifth, the learning atmosphere factor, the psychological atmosphere reflected in the emotional reactions of all school personnel, including teachers and students.

Then based on interviews from physical education teachers that the lack of interest in learning physical education in SMA Negeri 8 Medan is seen from the way students take 
part in the learning process where they often argue that they do not have a network, no examples of motion, do not have tools and are unable to perform the instructed movements. This information was obtained from a physical education teacher at SMA Negeri 8 Medan through an open interview by WhatsApp.

Based on the problems that occurred during the pandemicovid 19 period, researchers are very interested in implementing EDMOD and Google Classroom. Edmodo is one component of the learning service that is downloaded by the application on the Android / iPhone. This application is perfect for students, teachers, lecturers, office employees and professionals who like to make questions and send videos, pictures, and so on. In this Edmodo platform both teachers and students can interact with each other easily. Of course this will facilitate learning activities such as giving assignments, taking exams, quizzes, and much more. For Edmodo students this will help them to be more disciplined and collective in learning because usually the assignment given by the teacher is given a deadline.

Then e-learning uses Google Classroom. Literature review through the Google Classroom application assumes that the learning objectives will be more easily realized and full of meaning. Therefore, the use of Google Classroom actually makes it easier for teachers to manage learning and convey information appropriately and accurately to students (Hardiyana. 2015). Teachers can take advantage of various features found in Google Classroom such as assignments, grading, communication, time-cost, archive courses, mobile applications, and privacy. Virtual class (virtual class) is a class based on the web, where teachers and students can interact anytime and anywhere without being limited by space and time. Just like in a conventional classroom, In learning that takes place in a virtual classroom, students and teachers can interact with each other, which means students enter the virtual classroom at the same time. Google classroom (or in Indonesian, namely the Google classroom) is a learning platform that can be allocated to any scope of education which is intended to help find solutions to the difficulties experienced in making paperless assignments. This software has been introduced as part of Google Apps for Education (GAFE) since August 12, 2014. This application makes it easier for teachers and students to carry out the learning process more deeply. This is because both teachers and students can collect assignments, distribute assignments.

\section{Research Methods}

The research was conducted using an experimental method. The experimental method is a research method used to find the effect of certain treatments (Sugiyono, 2010: 12). In this study, this research is to compare two different e-learning, namely google classroom and edmodo with variables. Attributes of student learning interest consisting of high learning interest and low learning interest.

In accordance with the research design, there are two kinds of data that must be collected, namely: (1) data on physical education learning outcomes, physical fitness material which includes a pull up test for male students and a sit-up test for female students, and (2) data about student interest in learning. To obtain data on physical education learning outcomes, physical fitness material and student interest data, tests and measurements were carried out. To measure the learning outcomes of physical education, physical fitness material and student interest in learning, a research instrument was made. 


\section{Results and Discussion}

This research is an experimental study consisting of two variables, namely the dependent variable and the independent variable. The dependent variable is in the form of physical education learning outcomes, while the independent variable is learning, namely the edmodo e-learning treatment and the e-learning google classroom treatment. As well as the attribute variable is high interest in learning and low interest in learning. The data for the learning interest variable was obtained from the data of students who were tested for their ability as many as 72 (seventy two) people then divided into treatment groups for each cell of 10 people who were given e-learning edmodo treatment and e-learning google classroom treatment for 6 (six) Sunday. The manipulation of the learning treatment was carried out from the beginning of the experiment to the end of the learning treatment, both of which were carried out during the study. The data on the results of pull ups and sit ups, by the judges on students when doing a physical fitness test, so that the learning outcomes are the influence of the learning process carried out. The following is a summary of the calculation of the statistical values for each treatment group.

Table 1. Summary of Statistical Calculation Results

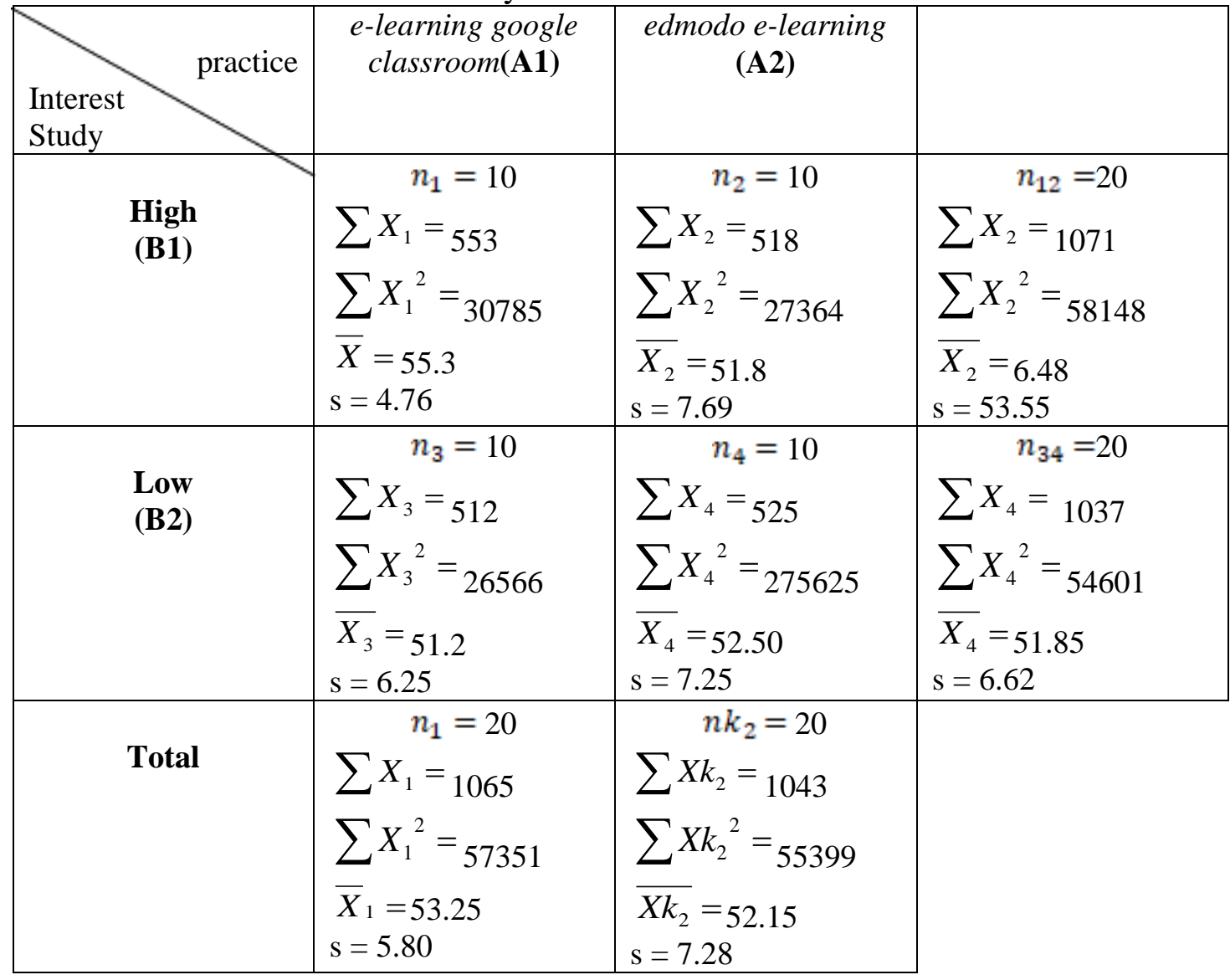

Results of physical fitness tests (pull ups and sit ups), Group of students treated with e-learning google classroom. Overall (Group A2). From the data on the results of physical fitness tests (pull ups and sit ups), the whole group of students who were given the elearning google classroom treatment. Obtained a range between 42 to 62 , there is an average price of 53.25 and the standard deviation of 5.80. As well as the frequency distribution as shown in table 2 below 
Table 2. Frequency distribution of physical fitness test results (pull ups and sit ups) of groups of students treated with google classroom e-learning. Overall (A1)

\begin{tabular}{|c|c|c|c|c|}
\hline No. & Interval Class & F. Absolute & F. Relative & F. Cumulative \\
\hline 1. & $42-45$ & 3 & 15 & 15 \\
\hline 2. & $46-49$ & 2 & 10 & 30 \\
\hline 3. & $50-53$ & 4 & 20 & 50 \\
\hline 4. & $54-57$ & 6 & 30 & 80 \\
\hline 5. & $58-61$ & 4 & 20 & 95 \\
\hline 6. & $62-65$ & 1 & 10 & 100 \\
\hline \multicolumn{2}{|c|}{ amount } & 20 & 100 & \\
\hline
\end{tabular}

Results of physical fitness tests (pull ups and sit ups), a group of students who were given edmodo e-learning treatment. Overall. (Group A2). From the data on the results of the physical fitness test (pull ups and sit ups), the group of students who were given the Edmodo e-learning treatment, as a whole. Obtained a range between 42 to 65 , there is an average price of 52.15 and the standard deviation of 7.28 And the frequency distribution as shown in table 3, as follows.

Table 3. The frequency distribution of the results of the physical fitness test (pull ups and sit ups) of the group of students treated with Edmodo e-learning, Overall (A2).

\begin{tabular}{|c|c|c|c|c|}
\hline No. & Interval Class & F. Absolute & F. Relative & F. Cumulative \\
\hline 1. & $42-46$ & 5 & 25 & 25 \\
\hline 2. & $47-51$ & 5 & 25 & 50 \\
\hline 3. & $52-56$ & 5 & 25 & 75 \\
\hline 4. & $57-61$ & 2 & 10 & 85 \\
\hline 5. & $62-66$ & 3 & 15 & 100 \\
\hline \multicolumn{2}{|r|}{ amount } & 20 & 100 & \\
\hline
\end{tabular}

The distribution of the frequency distribution of the results of the physical fitness test (pull ups and sit ups), the whole group of students who were given e-learning education treatment, is presented on the histogram as follows. Results of physical fitness tests (pull ups), groups of students who have high learning interest. Overall (Group B1).

From the data on the results of the physical fitness test (pull up) groups of students who have a high interest in learning. Obtained a range between 42 to 65 , there is an average price of $\bar{x}=53.55$ and the standard deviation of 6.48 and the frequency distribution as shown in table 4 below

Table 4. Frequency distribution of physical fitness test results (pull ups), groups of students who have high learning interest. Overall (B1).

\begin{tabular}{|c|c|c|c|c|}
\hline No. & Interval Class & F. Absolute & F. Relative & F. Cumulative \\
\hline 1. & $42-46$ & 3 & 15 & 15 \\
\hline 2. & $47-51$ & 3 & 15 & 30 \\
\hline 3. & $52-56$ & 7 & 35 & 65 \\
\hline 4. & $57-61$ & 4 & 20 & 85 \\
\hline 5. & $62-66$ & 3 & 15 & 100 \\
\hline \multicolumn{2}{|r|}{ amount } & 20 & 100 & \\
\hline
\end{tabular}


The distribution of the frequency distribution of the results of the physical fitness test (pull up), groups of students who have high learning interest, is presented on the histogram as follows.

3.1. Results of physical fitness tests (sit ups), groups of students who have low learning interest. Overall (Group B2)

From the data on the results of the physical fitness test (sit up), the group of students who have low learning interest. Obtained a range between 42 to 64, there is an average price of 51.85 and the standard deviation of 6.62 and the frequency distribution as shown in table 5 below.

Table 5. Frequency distribution of physical fitness test results (sit ups), groups of students who have low learning interest. Overall (B2)

\begin{tabular}{|c|c|c|c|c|}
\hline No. & Interval Class & F. Absolute & F. Relative & F. Cumulative \\
\hline 1. & $42-45$ & 5 & 25 & 25 \\
\hline 2. & $46-49$ & 3 & 15 & 40 \\
\hline 3. & $50-53$ & 3 & 15 & 55 \\
\hline 4. & $54-57$ & 6 & 30 & 85 \\
\hline 5. & $58-61$ & 1 & 5 & 90 \\
\hline 6. & $62-65$ & 2 & 10 & 100 \\
\hline \multicolumn{2}{|r|}{ amount } & 20 & 100 & \\
\hline
\end{tabular}

Distribution of frequency distribution of physical fitness test results (sit ups), groups of students who have low learning interest. presented on the following histogram. The results of the physical fitness test (pull up) given the google classroom e-learning treatment for groups of students who have high learning interest. (Group A1B1).

From the data on the results of the physical fitness test (pull-up) given the google classroom e-learning treatment to groups of students who have high learning interest.

Obtained a range between 47 to 62 , there is an average price of $\bar{x}=55.3$ and the standard deviation of $s=4.76$. As well as the frequency distribution as shown in table 6 below.

Table 6. Frequency distribution of physical fitness test results (pull up), which is treated with google classroom e-learning to groups of students who have high learning interest (A1B1).

\begin{tabular}{|c|c|c|c|c|}
\hline No. & Interval Class & F. Absolute & $\begin{array}{c}\text { F. } \\
\text { Relative }\end{array}$ & F. Cumulative \\
\hline 1. & $47-50$ & 1 & 10 & 10 \\
\hline 2. & $51-54$ & 2 & 30 & 40 \\
\hline 3. & $55-58$ & 2 & 30 & 70 \\
\hline 4. & $59-62$ & 3 & 10 & 80 \\
\hline \multicolumn{2}{|r|}{ amount } & 10 & 100 & \\
\hline
\end{tabular}

The distribution of the frequency distribution of the results of the physical fitness test (pull up), which is given the google classroom e-learning treatment to groups of students who have a high interest in learning. presented on the following histogram. Results of physical fitness tests (sit ups) given google classroom e-learning treatment in groups of students with low learning interest (group A1B2). 
From the data on the results of the physical fitness test (sit-up) given the google classroom e-learning treatment to groups of students who have low learning interest. Obtained a range between 42 to 59, there is an average price of $\bar{x}=51.20$ and the standard deviation of $s=6.25$. As well as the frequency distribution as shown in table 7 below.

Table 7. Frequency distribution of physical fitness test results (sit ups), which is treated with google classroom e-learning to groups of students who have low learning interest (A1B2).

\begin{tabular}{|c|c|c|c|c|}
\hline No. & Interval Class & F. Absolute & F. Relative & F. Cumulative \\
\hline 1. & $42-45$ & 3 & 30 & 30 \\
\hline 2. & $46-49$ & 1 & 10 & 40 \\
\hline 3. & $50-53$ & 1 & 10 & 50 \\
\hline 4. & $54-57$ & 4 & 40 & 90 \\
\hline 5 & $58-61$ & $\mathbf{1}$ & 10 & 100 \\
\hline \multicolumn{2}{|c|}{ amount } & 10 & 100 & \\
\hline
\end{tabular}

The distribution of the frequency distribution of the results of the physical fitness test (sit up), which is given the google classroom e-learning treatment to groups of students who have low learning interest. Presented on the following histogram. The results of the physical fitness test (pull up) given the Edmodo e-learning treatment in a group of students who have high learning interest. (Group A2B1).

From the data on the results of the physical fitness test (pull-up) which was given the Edmodo e-learning treatment to a group of students who had high learning interest. Obtained a range between 42 to 65 , there is an average price of $\bar{x}=51.80$ and the standard deviation of $s=7.69$. As well as the frequency distribution as shown in table 8 below.

Table 8. Frequency distribution of physical fitness test results (pull up), which is treated by Edmodo e-learning in groups of students who have high learning interest (A1B1).

\begin{tabular}{|c|c|c|c|c|}
\hline No. & Interval Class & F. Absolute & F. Relative & F. Cumulative \\
\hline 1. & $42-47$ & 4 & 40 & 40 \\
\hline 2. & $48-53$ & 2 & 20 & 60 \\
\hline 3. & $54-59$ & 2 & 20 & 80 \\
\hline 4. & $60-65$ & 2 & 20 & 100 \\
\hline \multicolumn{2}{|r|}{ amount } & 10 & 100 & \multicolumn{1}{c}{} \\
\cline { 1 - 3 } & &
\end{tabular}

The distribution of the frequency distribution of the results of the physical fitness test (pull up), which is given the Edmodo e-learning treatment to groups of students who have high learning interest. presented on the following histogram. The results of physical fitness tests (sit ups) which are given the treatment of e-learning edmodo in a group of students who have low learning interest. (Group A2B2).

From the data on the results of the physical fitness test (sit-ups) which were given the Edmodo e-learning treatment on groups of students who had low learning interest.

Obtained a range between 42 to 64 , there is an average price of $\bar{x}=52.50$ and the standard deviation of $s=7.24$. As well as the frequency distribution as shown in table 9 below. 
Table 9. Frequency distribution of physical fitness test results (sit ups), which is treated by Edmodo e-learning in groups of students who have low learning interest (A2B2).

\begin{tabular}{|c|c|c|c|c|}
\hline No. & Interval Class & F. Absolute & F. Relative & F. Cumulative \\
\hline 1. & $42-47$ & 3 & 30 & 30 \\
\hline 2. & $48-53$ & 3 & 30 & 60 \\
\hline 3. & $54-59$ & 2 & 20 & 80 \\
\hline 4. & $60-65$ & 2 & 20 & 100 \\
\hline \multicolumn{2}{|c|}{ amount } & 10 & 100 & \\
\hline
\end{tabular}

The distribution of the frequency distribution of the results of the physical fitness test (sit-up), which is given the Edmodo e-learning treatment to groups of students who have low learning interest presented on the following histogram.

Table 10. Summary of Normality Test Results with the Liliefors Test.

\begin{tabular}{|c|c|c|c|c|}
\hline Group & $\mathbf{n}$ & $L_{0}$ & $\begin{array}{c}L_{t} \\
\alpha=0,05\end{array}$ & Conclusion \\
\hline & & & & \\
& 20 & 0.0717 & 0.190 & Normal \\
& 20 & 0.0960 & 0.190 & Normal \\
1 & 20 & 0.1064 & 0.190 & Normal \\
2 & 20 & 0.1664 & 0.190 & Normal \\
3 & 10 & 0.0148 & 0.258 & Normal \\
4 & 10 & 0.0879 & 0.258 & Normal \\
5 & 10 & 0.0020 & 0.258 & Normal \\
6 & 10 & 0.0251 & 0.258 & Normal \\
7 & & & & \\
\hline
\end{tabular}

Information:

Group 1: Groups of students who were given the e-learning google calssroom as a whole. (A1)

Group 2 : Groups of students who were given edmodo e-learning treatment as a whole. (A2)

Group 3 : $\quad$ Group of students who have high learning interest, as a whole (B1)

Group 4: The group of students who have low interest in learning, as a whole. (B2)

Group 5 : Groups of students who have high learning interest who are given the e-learning google calssroom treatment. (A1B1)

Group 6 : Groups of students who have low learning interest, who are given the e-learning google calssroom treatment. (A1B2)

Group 7: $\quad$ Groups of students who have a high interest in learning who are given the edmodo e-learning treatment. (A2B1)

Group 8: $\quad$ Groups of students who have low learning interest, who are given the edmodo e-learning treatment. (A2B2) 


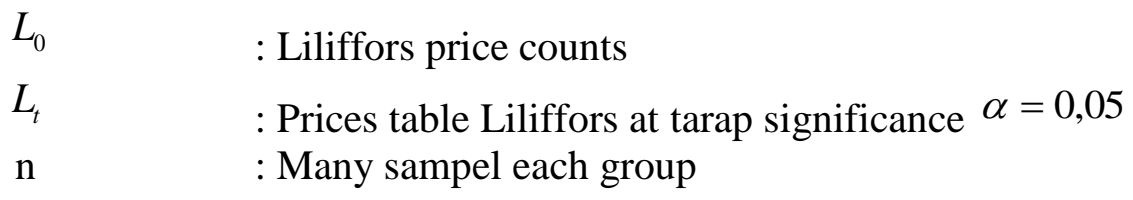

\subsection{Homogeneity Test}

The next analysis requirement that must be carried out is the homogeneity test which aims to determine whether the variance between the existing groups is homogeneous. The homogeneity test of the result scores (pull ups and sit ups) in Physical Fitness in each sample group was carried out using the Barlett test at the significance level $\alpha=0.05$. Homogeneity testing includes groups $\mathrm{A} 1$ and $\mathrm{A} 2$, groups $\mathrm{B} 1$ and $\mathrm{B} 2$, as well as groups A1B1, A1B2, A2B1 and A2B2.

\section{a. Homogeneity Test of Variance for Groups A1 and A2}

The sample in this group each consisted of group A1, totaling 20 (nA1) and group A2, totaling 20 (nA2). The summary of the results of the homogeneity test in this study can be seen in table 11 below.

Table 11. Summary of Homogeneity Test Results for Groups A1 and A2.

\begin{tabular}{|c|c|c|c|c|c|c|}
\hline $\begin{array}{c}\text { Sample } \\
\text { Group }\end{array}$ & $\begin{array}{c}\text { Variance } \\
(\mathrm{Si} 2)\end{array}$ & $\begin{array}{c}\text { Combined } \\
\text { Variants }\end{array}$ & $\mathbf{D b}$ & $\chi^{2}{ }_{h}$ & $\begin{array}{c}\chi^{2}{ }^{2} \\
\alpha=0,05\end{array}$ & Conclusion \\
\hline $\mathbf{A 1}$ & $\mathbf{5 2 . 9 8}$ & $\mathbf{4 3 . 3 2 3 6 8}$ & $\mathbf{3 8}$ & $\mathbf{1 . 2 5 8 6}$ & $\mathbf{3 , 8 4 0}$ & Homogeneous \\
$\mathbf{A 2}$ & $\mathbf{3 3 . 6 7}$ & $\mathbf{4}$ &
\end{tabular}

From the calculation results as shown in the table above are obtained $\chi^{2}{ }_{h}$ smaller than $\chi^{2}{ }_{t}\left(\chi^{2}\right.$ hitung $\left.=1.2586<\chi^{2}{ }_{\text {tabel }}=3.840\right)$. Thus H0 is accepted, which means that the variance of the data for groups A1 and A2 comes from a homogeneous population.

\section{b. Homogeneity Test of Group B1 and B2 Variances}

The samples in this group each consisted of group B1 which amounted to 20 (nB1) and group B2 which amounted to 20 (nB2). The summary of the results of the homogeneity test in this study can be seen in table 12 below.

Table 12. Summary of Homogeneity Test Results for Groups B1 and B2.

\begin{tabular}{|c|c|c|c|c|c|c|}
\hline $\begin{array}{l}\text { Sample } \\
\text { Group }\end{array}$ & $\begin{array}{c}\text { Variance } \\
\text { (Si2) }\end{array}$ & $\begin{array}{l}\text { Combined } \\
\text { Variants }\end{array}$ & Db & $\chi_{h}^{2}$ & $\begin{array}{c}\chi^{2}{ }_{t} \\
\alpha=0,05\end{array}$ & Conclusion \\
\hline $\begin{array}{l}\text { B1 } \\
\text { B2 }\end{array}$ & $\begin{array}{l}41.94 \\
43.82\end{array}$ & 42,881 & 38 & 0.0118 & 3,840 & $\begin{array}{c}\text { Homogeneou } \\
\text { S }\end{array}$ \\
\hline
\end{tabular}

From the calculation results as shown in the table above are obtained $\chi^{2}{ }_{h}$ smaller than $\chi^{2}{ }_{t}\left(\chi^{2}{ }_{\text {hitung }}=0,0118<\chi^{2}\right.$ tabel $\left.=3,840\right)$. Thus H0 is accepted, which means that the data variance of groups B1 and B2 comes from a homogeneous population.

\section{c. Homogeneity Test of Variance for Groups A1B1, A1B2, A2B1 and A2B2}

The samples in this group each consisted of 10 (n1) A1B1 groups, 10 (n2) A1B2 groups, 10 (n3) A2B1 and 10 (n4) groups. The summary of the results of the homogeneity test in this study can be seen in table 13 below. 
Table 13. Summary of Homogeneity Test Results for Groups A1B1, A1B2, A2B1 and A2B2.

\begin{tabular}{|c|c|c|c|c|c|}
\hline $\begin{array}{c}\text { Sample } \\
\text { Group }\end{array}$ & $\begin{array}{c}\text { Variance } \\
\mathbf{( S i 2})\end{array}$ & $\begin{array}{c}\text { Combined } \\
\text { Variants }\end{array}$ & $\chi^{2}{ }_{h}$ & $\begin{array}{c}\chi^{2}{ }_{t} \\
\alpha=0,05\end{array}$ & Conclusion \\
\hline A1B1 & $\mathbf{2 2 . 6 7}$ & & & & \\
A1B2 & $\mathbf{3 9 . 0 7}$ & & & & Homogeneou \\
A2B1 & $\mathbf{5 9 . 0 7}$ & $\mathbf{4 3 , 3 2 8}$ & $\mathbf{2 , 2 4 1}$ & $\mathbf{7 , 8 1 0}$ & $\mathbf{S}$ \\
A2B2 & $\mathbf{5 2 . 5}$ & & & & \\
\hline
\end{tabular}

Information:

A1B1 group: Groups of students who have high learning interest who are given the e-learning google calssroom treatment.

A1B2 group: Groups of students who have low learning interest, who are given the e-learning google calssroom treatment.

A2B1 group: Groups of students who have a high interest in learning who are given the edmodo e-learning treatment.

A2B2 group: Groups of students who have low learning interest, who are given the edmodo e-learning treatment.

From the calculation results as shown in the table above are obtained $\chi^{2}{ }_{h}$ smaller than $\chi^{2}{ }_{t}\left(\chi^{2}\right.$ hitung $\left.=2,241<\chi_{\text {tabel }}^{2}=7.810\right)$. Thus H0 is accepted, which means that the data variance of groups A1B1, A1B2, A2B1 and A2B2 comes from a homogeneous population.

Overall, the requirements of the analysis on normality and homogeneity testing have been met so that it can be continued to hypothesis testing

\subsection{Hypothesis Testing and Discussion}

From the results of the normality and homogeneity test, it was found that the research data on the results scores (pull ups and sit ups) in Physical Fitness were normally distributed and had homogeneous variances, so the requirements for data analysis had been met. Furthermore, hypothesis testing was carried out by means of two-way Analysis of Variance (ANOVA), at the level of significance $\alpha=0,05$ can be done. Two-way analysis of variance is intended to test the main effect hypothesis. With statistical hypothesis $H_{0}: \mu_{1}=\mu_{2}$ and $H_{1}: \mu_{1} \neq \mu_{2}$ Where $H_{0}$ will be rejected if $F_{0}>F_{t}$. This means that there is a difference between the two groups being compared. And continued with the Tukey-Test.

From the research results will also be tested the hypothesis about the interaction between the provision of plyometric training and interest in learning to the results (pull ups and sit ups) in Physical Fitness. If there are differences and interactions between groups, the analysis is continued with the Tukey-Test to test the simple effect hypothesis. This test aims to determine which group is more influential than the groups being compared.

Hypothesis testing using the two-way analysis of variance (ANOVA) technique. The summary of the calculation results can be seen in table 14, below. 
Table 14. Summary of Two-way Variance Analysis Results

\begin{tabular}{|c|c|c|c|c|c|c|}
\hline $\begin{array}{c}\text { Source of } \\
\text { Variance }\end{array}$ & JK & Db & RJK & $F_{\text {count }}$ & \multicolumn{2}{|c|}{ Ftable } \\
\hline Among & 12.1 & 1 & 12.1 & $0.279 *$ & 4.11 & 7.39 \\
\hline Between B & 28.9 & 1 & 28.9 & $0.667 *$ & 4.11 & 7.39 \\
\hline $\begin{array}{c}\text { AB } \\
\text { interactions }\end{array}$ & 57.6 & 1 & 57.6 & $1,329 *$ & 4.11 & 7.39 \\
\hline In (D) & 1559.8 & 36 & 43.32778 & - & - & - \\
\hline Total & 2110982 & 39 & - & - & - & - \\
\hline
\end{tabular}

\section{Interest:}

$J K \quad:$ Sum of the Squares

$J K_{A} \quad$ : Number of Squares Variable A (e-learning treatment)

$J K_{B} \quad$ : Sum of Squares of Variable B (Interest in learning)

$J K_{A B}:$ Sum of the Squares of the Interaction AB

$J K_{d} \quad:$ Sum of the Squares in

$J K_{t} \quad:$ Sum of total squares

$d b \quad:$ Degrees of freedom

$R J K \quad$ : Average of the Squares

$F_{0} \quad$ : Price $F_{\text {hitung }}$

$F_{t} \quad$ : Price $F_{\text {tabel }}$

* : : Significant at the level $\alpha=0,05$

** : Very significant at the level $\alpha=0,01$

\section{Conclusion}

Based on the research conducted, several conclusions can be explained, as follows:

1. Overall results, the group of students who were given e-learning google classroom treatment was better, than the group of students who were given e-learning edmodo treatment.

2. For students who have high learning interest, the group of students who are given elearning google classroom treatment is better, than the group of students who are given e-learning edmodo treatment. Judging from the mean value in the two treatment groups there is a difference, statistically the difference is quite significant. This means that the two treatments are equally good in providing an effect on test results (pull ups and sit ups) in physical fitness.

3. For students who have low learning interest, physical fitness results are given better elearning treatment than those given google classroom e-learning treatment.

4. There is an interaction between e-learning treatment (A) and interest in learning (B) on test results (pull ups and sit ups) in physical fitness. 


\section{Suggestion}

There are several suggestions put forward in this study, namely:

1. E-learning google classroomboth used to provide practical learning material. So the physical education teacher at SMA Negeri 8 Medanda is recommended to use e-learning google classroom to be used as an online learning guide in the practical learning process, especially physical fitness material.

2. This study only examines the results (pull ups and sit ups) in physical fitness. It is advisable to research more about physical fitness with different test forms and measurements.

\section{References}

Abdoellah, (1999). Theory and Practice Curriculum Development. Jakarta: Primary Media Style.

Abdul Kadir Ateng. (1992). Principles and Foundations of Physical Education. Ministry of Education and Culture, Directorate General of Higher Education, Educational Personnel Development Project.

Adang Suherman. (2000). Basics of Physical Education. Ministry of Education and Culture, Directorate General of Primary and Secondary Education, Section D-III Junior Secondary Teacher Upgrading Project.

Allen, Michael. (2013).Michael Allen's Guide to E-learning. Canada: John Wiley \& Sons.

Ardiansyah, Ivan. (2013). Exploration of Communication Patterns in Discussions Using Moddle in Chemistry Learning Simulation Lectures, University of Education Indonesia, Bandung-Indonesia.

Arsani et al. (2020). Differences in Motivational Orientation in Physical Education in terms of Gender Differences. Budapest International Research and Critics in Linguistics and Education (BirLE) Journal. P. 1428-1434

Asyhar, R., (2012). Creatively developing learning media. Bandung: Rosdakarya.

Aunurrahman. (2012). Learning and Learning. Bandung: CV Alfabeta.

Ega Trisna Rahayu. (2013). Physical Education Learning Strategies. Implementation of Physical Education, Sports and Health Learning. Bandung: CV Alfabeta.

Fathurrahman. (2015). 'The Concept of Persuasive Da'wah Communication in the Perspective of the Qur'an', AT-TABSYIR: Journal of Islamic Broadcasting Communication,

Gunawan, FI \& Sunarman, SG, (2018). Development of Virtual Classroom with Google Classroom in Problem Solving Skills on Vector Topics for High School Students to Support Learning.

Hakim, AB, (2016). The Effectiveness of Using E-Learning Moodle, Google Classroom and Edmodo. I-STATEMENT: Information System and Technology Management, 2 (1).

Hamalik, Oemar. (2010). Teaching and Learning Process. Jakarta: PT. Earth Literacy

Hanum, NS, (2013). E-Learning Effectiveness as Learning Media (Evaluation Study of ELearning Learning Model of Telkom Sandhy Putra Purwokerto Senior High School). Journal of Vocational Education, 3 (1).

Husdarta. (2011). Physical Education Management. Bandung: Alfabeta.

Makmum Khairani. (2013). Learning Psychology. Yogyakarta: Aswaja Pressindo.

Miarso, yusufhadi. (2007). Sowing the seeds of educational technology. Jakarta. Kencana Prenada Media Group.

Miarso, Y., (2004). Sowing the seeds of educational technology, Kencana. 
Moleong, LJ. (2004). Qualitative Research Methodology Revised Edition. Bandung: Rosdakarya.

Novianti et al. (2020). Improvement of Physical, Honesty, Discipline and Cooperation in Class IV Elementary School Students through Circuit Training Learning Model. P. Budapest International Research and Critics in Linguistics and Education (BirLE) Journal. P. 244-250

Parwoto, A. (2007). Inferential statistics laboratory guide. Jakarta: Gramedia Widiasarana Indonesia.

Pranoto, Alvini. Et al. (2009). Science and Technology. Jakarta: PT Gramedia Pustaka Utama.

Prawiradilaga, Dewi Salma et al. (2007). Educational Technology Mozaik. Jakarta. Kencana Pernada Media Group.

Rusli Lutan. (2000). Physical Education Teaching and Learning Strategies. Ministry of Education and Culture, Directorate General of Primary and Secondary Education, Section D-III Junior Secondary Teacher Upgrading Project.

Rusli Lutan. (2000). Measurement and Evaluation of Physical Education and Health. Ministry of Education and Culture, Directorate General of Primary and Secondary Education, Section D-III Junior Secondary Teacher Upgrading Project.

Samsudin. (2008). The role of interactive multimedia in learning. accessed on 3/20/2018 on pagehttp://eprints.uny.ac.id/7848/3/BAB\%202-08403244039.pdf.

Sanjaya, Vienna. (2010). Educational Process Standards Oriented Learning Strategy. Jakarta: Prenada Media Group

Sardiman, AM. (2009). Interaction and Learning Motivation. Jakarta: PT Rajagrafindo Persada.

Sarwono Wirawan Sarlito. (2000). Adolescent Psychology. Jakarta PT Grafindo Persada.

Smaldino, SE, Lowther, DL \& Russell, JD, (2008). Instructional technology and media for learning.

Slameto. (2010). Learning \& Influencing Factors. Jakarta: PT Rineka Cipta.

Soedjiarto. (2000). Relevant and Quality National Education Methods. Jakarta: Balai Pustaka.

Sugiyono. (2010). Educational Research Methods with Quantitative Approaches, Qualitative, and R \& D. Bandung: Alfabeta.

Sujana, Janti Gristinawati and Yuyu Yulia. (2005). Development of Libraries in Indonesia. Bogor: IPB Press.

Suyono, Harianto. (2015). Learning And Learning. Bandung: Youth Rosdakarya.

Syaiful Bahri Djamarah. (2011). Psychology of Learning. Jakarta: PT Rineka Cipta

Trianto. (2018). Designing Innovative-Progressive Learning Models. Jakarta: Kencana Prenada Media Group

Vasti, Safari. (2008).: 3. Interest Indicator.

Yamin, Martinis. (2009). Teacher Professionalization \& Implementation of KTSP. Jakarta: Echoes of Persada Pre,

Yrama Widya . (2014). Sports and Health Physical Education for SMA / SMK, Jakarta

Zamroni. (2012). Introduction to Educational Theory Development. Yogyakarta: Tiara Discourse 